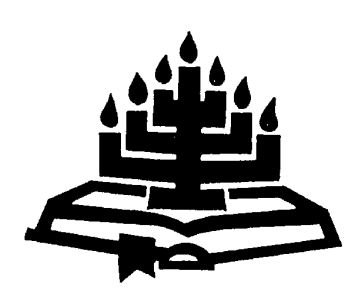

\title{
Die Heilige Gees en die Skriflesing in die samekoms van die gemeente
}

\author{
B.J. de Klerk \\ Praktiese Teologie \\ Skool vir Kerkwetenskappe \\ Potchefstroomse Universiteit vir CHO \\ POTCHEFSTROOM \\ E-pos: ontbjdk@puknet.puk.ac.za
}

\section{Abstract \\ The Holy Spirit and Scripture-reading in the gathering of the congregation}

The realisation of the presence of God in the gathering of the congregation is often hampered by the lack of emphasis on the communicative action, the Scripture-reading by which God directly talks to his congregation. In this article the basic theoretical exploration indicates that Scripture-reading is the way in which God addresses us as: "Here I am!" God discloses his power to bestow grace upon and judge the congregation. Scripture-reading as signifying communicative action in the service can be regarded as a continuation of the idea of God's presence implied by the tabernacle, temple, and synagogue - an idea also emphasised in New-Testament times and in the twentieth century. Scripture-reading is thus the binding and decisive factor in the meeting of God with his people. Some possibilities for the practical application of the independent Scripture-reading are indicated in this article.

\section{Probleemstelling}

In die bymekaarkomplek van gemeentes is die kanselbybel een van die mees deurslaggewende simbole: "Die groot Kanselbybel wat op die kansel lê (herinner) ons (saam met die kansel) simbolies aan die primaat van die Skrif in ons erediens" (Vos \& Pieterse, 1997:124). Nie-verbale kommunikasie is ingebed in die handeling waarin God regstreeks aan die woord kom - kommunikasie wat ons "Skriflesing" noem. Hierdie kommunikatiewe handeling in die samekoms van die gemeente staan in 'n kousale verhouding tot die ander handelinge. Dit beteken dat hierdie een handeling die ander oproep (De Klerk, 1987:315). Die verhouding 
van Skriflesing tot die ander handelinge van die samekoms, bewerk deur die kragtige werking van die Heilige Gees, is 'n kousale verhouding van die gemeenskap van God in Christus met sy vergaderde gemeente. Hierdie verhouding word gebou deur openbaring wat bring tot belydenis en aanbidding (De Klerk, 1987:316).

Die Heilige Gees gebruik die Skrif om die brug tussen God en gemeente en gemeentelede onderling te bou. Waarom maak die Gees juis van die Skrif gebruik en hoe maak Hy daarvan gebruik? Watter kraguitoefening het die Skriflesing op die samekoms van die gelowiges en hoe kan leser en hoorder onder die kragtige werking van die Woord kom? Wat doen die Gees terwyl die gemeente die Woord van God aanhoor?

Hierdie vrae is vandag aktueel omdat die gemeente "erediens" kan vier, sonder om in die teenwoordigheid van God te wees. Die werklikheid van God in die samekoms, die Bybelse spiritualiteit word nie net uitgewis deur wettiese prediking nie (Cilliers, 1996:108) maar veral ook deur die onderspeling van die kommunikatiewe handeling waarin God regstreeks met sy gemeente praat.

Deur 'n oorsig van die ontwikkeling van Skriflesing in die Ou-Testamentiese, sinagogale en Nuwe-Testamentiese erediens te verkry, kan sekere beginsels vir die Skriflesing afgelei word. Die betekenis en plek wat Skriflesing in die eerste eeue na Christus, in die sestiende-eeuse Reformasie en in die twintigste eeu gekry het, kan meehelp om uiteindelik 'n antwoord op die wesensbelangrike vraag te verkry, naamlik watter krag oefen God deur sy regstreekse spreke in die samekoms van die gemeente uit? Indien daar vanuit eksegetiese ondersoek en die ondersoek van die kerklike tradisie 'n basisteorie verkry sou kon word, en vasgestel kan word wat die stand van Skriflesing deur die eeue is, moet op praktyk-teoretiese vlak gesoek word na moontlike riglyne waarop die Skriflesing, as spreke van God, as belewing van God se teenwoordigheid in die samekoms, geherwaardeer kan word.

\section{Basisteoretiese verkenning en perspektiewe}

Waarom maak die Heilige Gees juis van die Heilige Skrif as medium gebruik om God se teenwoordigheid in die samekoms te laat beleef? En hoe maak die Heilige Gees van die Skriflesing hierin gebruik? Hy maak Hom vir die verbondsgemeente hoorbaar en verstaanbaar sodat hulle uit dit wat Hy sê, Hom kan ken en met Hom innige gemeenskap kan belewe. Die misterie hiervan is dat God en 'n mens van nature wesensverskillend is, en tog kan 'n mens nie net God se stem hoor nie, maar dit ook verstaan. Hierdie oorbrugging van die taal- en verstaanprobleem is die werk van die Heilige Gees, wat God se Woord deur Goddelike inspirasie aan mense gegee het. 


\subsection{Die Skriflesing is God se kragsuitoefening}

Hoewel die woorde wat die gemeente in die Skriflesing hoor, in mensetaal kom, ontvang hulle in die Skriflesing hierdie woorde nie as mensewoorde nie maar as die Woord van God (1 Tes. 2:13; vgl. Cornelius, 1991:40). Die rede hiervoor is eerstens dat die Skriflesing (Paulus se prediking) nie maar net in woorde kom nie maar met krag, omdat dit bewerk wat dit verkondig, naamlik redding van mense en bevryding vir hulle van afgode, sondes en sondemagte. Die Woord breek die pad oop en oorwin die teenstand. Daar is geestelike dinamiet in die Woord wat afgode kan uitwis (1 Tes. 1:9). Die Woord het egter nie net afbrekende krag nie, ook opbouende krag, byvoorbeeld om God te dien. Die Woord kom deur die Heilige Gees, en die Gees is ook die krag van God (Rom. 15:13, 19; vgl. Guerra, 1995:168), want die Gees dring deur tot die hart van die mens en skep die regte gehoor van die Woord. Die instrumente wat die Woord van die Gees ontvang het, praat en skryf in volle versekerdheid dat, terwyl hulle preek, die krag van God aan die werk is. Die uitwerking van hierdie woorde op die eerste hoorders in Tessalonika is dat hulle die Woord aangeneem het met 'n blydskap wat van die Heilige Gees kom. Dieselfde Gees wat die apostel toerus om met krag te preek, onderskraag die gemeente om ten spyte van baie moeilike omstandighede met blydskap te glo (Calvyn, 1961:337).

Die hoorders het die Woord nie net geglo nie maar ook innerlik daarop gereageer deurdat hulle die inhoud van die Woord aanneem (1 Tes. 2:13; vgl. Combrink, 1993:488). Hulle verwelkom die Woord nie as 'n woord van menslike oorsprong nie, maar ('n sterk teëstelling - alla) hulle aanvaar die Woord as die regstreekse spreke van God. Die gemeente het God as die Outeur van die boodskap herken en daarmee verby Paulus gekyk en hulle oë op God gerig om sy Woord te ontvang (Calvyn, 1961:347). Die gemeente reageer dus op die voorlesing van hierdie brief (Skriflesing) deur dit aan te hoor en aan te neem soos dit werklik is, naamlik as die Woord van God (vgl. Kol. 4:16; vgl. Vleugels, 1997:248-260).

Die vraag is: Hoe het dit gebeur dat die diepste geheimenisse van God in die Skrif opgeteken kon word? By Paulus word 'n aanverwante uitdrukking aangetref: "die hele Skrif is geïnspireer" (2 Tim. 3:16; vgl. Kim, 1997:33). 2 Timoteus 3:10-17 handel oor die gebruik en veral die bedoeling van die Skrif. Theopneustos is 'n baie uitsonderlike woord wat op die "asem" van of inspirering deur God wys (Louw \& Nida, 1989:418), en dui dus die werking van die Heilige Gees aan. God het deur sy Gees die skrywers van hierdie Heilige Skrifte op so 'n wyse in sy diens geneem dat hulle die woorde van God skryf. Die mens kan nie God aan ander mense openbaar nie. Hierdie openbaring moet deur God self gemaak word (Miller, 1997:120,121; Kim, 1997:152; Calvyn, 1964:330).

Deur hierdie onderskrywing van die organiese inspirasie van die Skrif en veral op grond van die feit dat die Heilige Gees God se Woord aan mense gee, heg hierdie 
ondersoek prinsipieel 'n bepaalde waarde aan die Skrif en daarmee aan die voorlesing van die Skrif in die erediens. Wat tydens die Skriflesing gehoor word, is die Woord van God. Anders gestel: God is met die Skriflesing regstreeks aan die Woord.

\subsection{Die Skriflesing is duidelik vir almal wat deur die Gees verlig} is

Wie opreg bely dat die hele Skrif "deur God ingegee" is (2 Tim. 3:16) en dat die Bybelskrywers "deur die Gees gedrywe" is (2 Pet. 1:21), moet daarmee nie alleen erken dat die Heilige Gees die Inspirator van die Skrif is nie maar dat die Gees óók die eintlike en onmisbare Eksegeet van die Skrif is. God laat nie net sy heilsdade in die geskiedenis plaasvind nie, maar sorg ook deur sy Heilige Gees dat ons 'n betroubare berig daaroor ontvang en - deur dieselfde Heilige Gees dat ons ook die berig reg verstaan (Van Houwelingen, 1993:51).

Die Gees tree in die proses van die verstaan van die Bybel as die eintlike Skrifverklaarder op. Daarom vereis die verstaan van die Skrif van elke hoorder 'n biddende gesindheid. Verder staan, teenoor Rome, wat die duisterheid van die Skrif leer, die perspicuitas (die duidelikheid) van die Skrif vas. Die Reformasie het teenoor Rome sterk beklemtoon dat die Bybelse boodskap begryp kan word deur almal wat biddend verlang om dit te verstaan (Brienen, 1987:180). Om die Bybel te verstaan is 'n gawe, nie 'n prestasie nie. 'n Mens kry dit op die knieë of glad nie. Toegepas op die Skriflesing in die erediens beteken dit dat die gelowige hoorder nie 'n ander eksegeet vir die verstaan van elke Skrifgedeelte nodig het nie. Daarom is God lewend teenwoordig in die samekoms en werk Hy aktief in sy regstreekse spreke kragtig in elke hoorder.

Die woord van die kruis oordeel en skei dié wat besig is om verlore te gaan (praesens) of besig is om gered te word (praesens) terwyl hulle die prediking beoordeel en dwaasheid of wysheid vind (Martin, 1995:60). Vir dié wat gered word, is die woord van die kruis 'n krag van God tot redding (vgl. Rom. 1:16). Wie besig is om verlore te gaan, beleef die prediking (Skriflesing) as dwaasheid wat niks aan hulle lewe doen nie. Die evangelie is nie maar net goeie advies aan mense of 'n boodskap oor God se krag nie, maar dit is God se krag (Braaij, 1993:73). God alleen kan mense uit die sondige wêreld red (vgl. 1 Kor. 1:8, 9), en die daad wat Hy verrig om dit te doen, is die prediking van die kruis. Wie die krag van die Woord van die kruis ervaar, is op die weg van redding, en as iemand op die weg bly, is dit alleen deur die krag van God. Dit is wat in die kommunikatiewe handeling van die Skriflesing gebeur.

Toegepas op die handeling van die Skriflesing in die erediens leer 1 Korintiërs 1:17-25 dat God in hierdie handeling sy reddende krag uitoefen en dat die voorlees en aanhoor van die Woord 'n skeidende werking het. Terwyl die Woord 
gelees word, is mense, deur hulle reaksie daarop, op die weg van redding en bly hulle daarop of is hulle besig om verlore te gaan. Hierdeur is dit duidelik dat Paulus die Skriflesing beskryf as 'n krag van God, waarvan die Heilige Gees die Oorsprong, Outeur en Bewerker is. Christus self word in hierdie gedeelte die krag van God genoem (1 Kor. 1:24; vgl. Liftin, 1994:193-201), omdat Hy die inhoud van die evangelie (Skrif) is. Juis vanweë sy Inhoud en Outeur het die Skrif en veral die aanhoor van die Skriflesing die resultaat dat dit die mense tot geloof, bekering en 'n nuwe lewe bring.

Die geheimenisse van God kan alleen deur mense verstaan word in soverre hulle genadiglik deur die Heilige Gees verlig is (vgl. Calvyn, 1986:395). Die wysheid van die mens kan nie God se geheimenisse verstaan nie (1 Kor. 2:6-9; vgl. Holleman, 1996:188; Liftin, 1994:217), maar God gee aan die gelowige deur sy Gees wysheid om Hom werklik te kan hoor, te ken en sy magtige teenwoordigheid sodoende te kan ervaar (vgl. Ef. 1:17, 18; Moritz, 1996:188; Arnold, 1989:85). Dat die wysheid van God wat deur die Gees in die Skrif geopenbaar word, alleen verstaan kan word deur mense wat die Gees het, blyk uit 1 Korintiërs 2:13-15 (Venter, 1992:3). Om die onderrig van die Gees te kan verstaan moet daar 'n ooreenstemming tussen die innerlike van die hoorder en die aard van die woorde bestaan. Die woorde van die Gees kan alleen deur mense van die Gees verstaan word.

\subsection{Die Skriflesing is luister na God}

Vir sowel voorleser as ontvanger (hoorder) van die Woord beteken dit dat hulle met die oog op die Skriflesing met die Heilige Gees vervul moet wees. Vir die voorleser beteken dit dat hy leeg moet wees van homself, van hoogmoed en gepaardgaande hoogdrawendheid, van bekommernis en spanning en van onopregtheid. Die hoorder moet ontledig wees van egoïstiese gedagtes, van bekommernis en vooropgestelde standpunte wat die Woord deur 'n sekere bril (byvoorbeeld politiek) sien. Tegelyk moet die voorleser en die hoorders op grond van die belofte van Lukas 11:13 bid om die Heilige Gees en dat die Gees hulle sal vervul, dit wil sê hulle gedagtes sal beheer en sodoende vir die Woord oopmaak (Goulder, 1994:500; Evans, 1990:486). Die voorleser sal die handeling van die Skriflesing op so 'n wyse verrig dat die inspirasie van die Skrif, deur 'n Geesvervulde voorleser volkome duidelik na die hoorder deurgegee word. Die voorlesing kan dan in dieselfde gees as die oorspronklike prediking gedoen word, naamlik met krag en deur die Heilige Gees en met volle oortuiging (vgl. 1 Tes. 1:5). Die hoorders wat deur dieselfde Gees beheer word sal dan, selfs onder moeilike omstandighede, die woord aanneem met 'n blydskap wat van die Heilige Gees kom (1 Tes. 1:6; vgl. Cornelius, 1991:62). Juis omdat die eenheid van die Heilige Gees en die Woord in die handeling van die Skriflesing bely word en die Heilige Gees die hoorder begelei om die Skriflesing as Woord van God aan te 
neem en toe te eien, vind daar deur die Skriflesing mededeling deur die Gees plaas (Trimp, 1983:25). Hiermee word nie net inligting bedoel nie maar ook en veral die gee van geestelike gawes soos genade, versoening, vrede, geregtigheid van God.

Dat bostaande ook vir 'n gelowige se persoonlike omgaan met die Skrif geld, verminder nie die belangrikheid van die voorlesing van die Skrif in die samekoms van die gemeente nie. Die Ou Testament is in die sinagogale erediens aan die vergadering van gelowiges voorgelees (Luk. 4; vgl. Johnson, 1991:78-82; Squires, 1993:138; Hand. 13; Kistemaker, 1990:467) en die meeste van die Nuwe-Testamentiese briewe is aan gemeentes geskryf met die bedoeling dat dit aan die gemeente as geheel voorgelees moet word (vgl. Kol. 4:16; Vleugels, 1997:241; Guthrie, 1966:174). Die inhoud van die boeke van die Skrif vereis dat gelowiges dit gesamentlik moet hoor en dat hulle gesamentlike toesegging of opdragte ontvang (bv. Ef. 4; Heb. 10; vgl. Hust, 1990:99).

Die ontmoeting van God met die gemeente is veral 'n dinamiese ontmoeting, want die Bybel bring nie bloot inligting nie maar bring God wat praat vir die gemeente (vgl. Heb. 1:1; vgl. Klijn, 1975:24). Die Woord kom uit die gedagtes van God, gaan uit van sy mond (vgl. 2 Tim. 3:16) en kom tot die mens in hoorbare taal - veral deur die Skriflesing. Hierdie Woord keer nie onverrigtersake na God terug nie: dit bring verlossing vir gelowiges tot stand en dit veroordeel die goddeloses (Young, 1972:384). Hiermee word uitgedruk dat God, terwyl Hy praat, dinamies werk en sy plan deur die uitspreek van sy Woord daadwerklik uitvoer (vgl. Joh. 12:48; Jer. 23:29 e.v.; Rom. 1:16; vgl. Braaij, 1993:76; Calvyn, 1965:172). God oefen deur die Skriflesing in die erediens soveel krag uit dat dit tot verandering of verharding van die mens se hart en wilslewe lei. Die hele mens word in hierdie dinamiese ontmoeting in beweging gebring, en die Gees maak in die Skriflesing geestelik dooie mense tot kinders van God.

Koole se vertrekpunt ten opsigte van die Skriflesing is die mag van die Woord. Hy wys daarop dat Calvyn teenoor die fluisterende woord van die priester by die heiliging van brood en wyn in die mis die clara voce, die helder, duidelik gesproke Woord stel. Hierdie Woord het die mag om in ons hart in te dring. Die Bybel as neergeskrewe en teboekgestelde Woord van God het oneindige waarde vir ons geloofslewe. En dit, sê Koole (1946:24), omdat God self in die Woord tot ons kom en sê: "Hier is ek! So is Ek en dit bly Ek vir julle!" Hy toon aan dat die opvoedkundige waarde van die Skriflesing maar bysaak is en dat die Skriflesing ten diepste nie die bedoeling het om ons Bybelkennis te vermeerder nie. Die bedoeling juis in die erediens is gemeenskap met God, die belewing van ware spiritualiteit. En daarom moet die Bybel nie net maar persoonlik in stilte gelees word nie, maar ook hardop in die erediens voorgelees word.

De voorlezing van het boek doet het Woord eruit ontspringen. Ik kan niet zeggen, dat de voorlezing het doode Woord levend maakt, want het Woord 
is niet dood. Maar ik kan wel zeggen, dat in de voorlezing het levende Woord zijn krag betoont. Het wordt daarin actueel, rechtstreeks en op de man af (Koole, 1946:27).

\subsection{Samevattende basis-teoretiese uitgangspunt}

Die Skriflesing is die wyse waarop God na ons toe kom en sê: "Hier is Ek!" In en deur die Skriflesing kom Christus om deur sy Gees in en aan ons te werk. In die voorlesing betoon die lewende Woord sy krag, want God kom aan die woord om die gemeente te begenadig en te beoordeel. In die voorlees van die Woord is God in die samekoms aktueel, regstreeks, op die man af aan die woord, en daarom is die Skrif bestem om in die vergadering van gelowiges voorgelees te word. Die Skriflesing is die selfkommunikasie van God wat na die gemeente toe kom, en sy spreke skep die moontlikhede en geleenthede om op die dinamiek van die Woord te reageer en sodoende gemeenskap met God in sy teenwoordigheid te beoefen. Die Skriflesing maak, omdat God regstreeks praat, die ontmoeting en gesprek moontlik, en juis deur die Skriflesing behou God in die erediens die inisiatief. Die Skriflesing is primêr daarvoor bedoel dat die gemeente God self kan hoor, deur sy stem en die inhoud van sy woorde Hom kan ken en die gemeente deur die regstreekse toesegging van genade en oordeel deur die Skriflesing opgebou kan word.

\section{Vasstelling van die stand van Skriflesing in die geskiedenis}

\subsection{Die Ou Testament}

Hahn (1973:7) praat van twee embrio's waaruit die Israelitiese erediens groei: die erediens van die "God van die vaders" uit die stamme van die woestyn (Alt, 1968:8) en die Jahwekultus wat met die Sinaitradisie geassosieer word (Von Rad, 1962:129). Wat die Sinaigebeure betref, bevat Eksodus 24:1-8 'n weergawe van die ontmoeting tussen God en die Israeliete. Hierdie ontmoeting bestaan uit vyf basiese strukturele elemente vir 'n ontmoeting tussen God en sy volk (Webber, 1982:24).

- Die eerste element is dat die byeenkoms deur God saamgeroep is: waar die volk God ontmoet, ontstaan 'n Q'hal Jahweh, 'n vergadering van God.

- Die tweede is dat die volk in 'n struktuur van verantwoordelikhede van leiers en ander gerangskik is. Elk is by die samekoms betrokke, en deelname word daarmee as 'n fundamentele aspek van die erediens aangedui.

- Die derde en belangrikste element in hierdie samekoms tussen God en Israel is die proklamering van God se Woord (Vos \& Pieterse, 1997:39). Dit is dus 
duidelik dat die ontmoeting nie kan plaasvind sonder dat die volk God hoor nie (Rogers, 1977:192).

- Ten vierde reageer die volk op die Woord deur gehoorsaamheid, en 'n essensiële aspek van die Joodse erediens is daarom die voortdurende hernuwing van persoonlike toewyding aan God.

- Die ontmoeting het 'n vyfde element waardeur die ooreenkoms of gebeure met die samekoms dramaties verseël word. In hierdie geval is dit offers aan die Here. In die tabernakel- en tempeldiens het die aksent op die offers geval, maar die Woord het steeds 'n belangrike deel daarvan gevorm (Barnard, 1981:79).

Die verskillende feeste wat in die tempel en die huise van die volk gesentreer het, was 'n belangrike wyse waarop die volk in 'n ontmoeting (erediens) met God verkeer het. In hierdie feeste gaan dit enersyds om 'n herdenking van God se werk in die loop van die geskiedenis en andersyds om God se voortdurende teenwoordigheid onder sy volk. Gedurende hierdie feeste is die Woord van God mondeling oorgedra (Breed \& Venter, 1996:66), want tydens die Paasfees as familiefees moes die vader die geskiedenis oorvertel, die familie deur die maaltyd begelei en die betekenis van die simbole verduidelik: "Dit is oor wat die Here vir my gedoen het toe ek uit Egipte getrek het" (Eks. 13:8). Veral by die Huttefees was daar duidelik tekens dat daar uit die Woord (Wet) voorgelees is (Van der Walt, 1982:46, Billerbeck, 1964:159).

\subsection{Die sinagogale erediens}

Die sinagogediens was 'n belangrike aanvulling vir die tempeldiens en was in twee dele verdeel: 'n gebedsdeel en 'n woorddeel (Hahn, 1973:10). Om die heidense invloede uit te skakel is die Tora sistematies deurgelees. Dit het in die plek van die offers gekom en die priesters is deur rabbi's vervang. Die diens was in 'n baie groot mate op die jeug (kleiner en groter kinders) gerig (Milligram, 1971:89 e.v.). Volgens die Misjna (Megilla iv:3-6) het die sinagogediens uit die volgende vyf dele bestaan: die Schema, die Tefilla, die Tora, die profete en die parafrase en uitleg van die teks (Targum; Barnard, 1981:94). Die Tora is in 54 gedeeltes (sedarim) ingedeel, en die gedeeltes is agtereenvolgens in die loop van een jaar deurgelees. Dit was die Babiloniese siklus (Vos \& Pieterse, 1997:141). In Palestina is die siklus oor drie jaar versprei en met die oog daarop is die Tora in 154 parashe verdeel (Van der Walt, 1982:46). Lank voor die Christelike era was die gebruik van 'n vaste en gereelde lees van die Tora in die byeenkomste gevestig. Omdat die Tora in vaste volgorde deurgelees is, is dit die lectio continua genoem en is die lees van die betrokke gedeelte van die Tora as 'n doel op sigself beskou en nie slegs met die oog op prediking daaroor nie (Mann, 1971:59). Naas die voorlesing van die wet het die voorlesing uit die profete later 
gekom. Dit is hoegenaamd nie aan mekaar gelykgestel nie, want waar die Tora agtereenvolgens gelees is, is die profete volgens ' $n$ bepaalde rooster van perikope gelees (die Haftora).

Omdat Jesus en sy dissipels en die apostel Paulus aan die sinagogediens deelgeneem het, het die Christene, selfs nadat hulle uit die sinagoge geban is, nog steeds die model daarvan in die Christelike erediens nagevolg (Vos \& Pieterse, 1997:247). Dit is veral die selfstandige en gereelde lees van die Skrif wat 'n blywende stempel op die Christelike kerk afgedruk het. Omdat die inligting oor die ontwikkeling van die erediens in die Nuwe Testament so gefragmenteerd is, is die navorsing oor die Skriflesing nie so eenvoudig nie (Webber, 1982:33). Die eerste Nuwe-Testamentiese gelowiges het 'n tyd lank die erediens in die sinagoge en tempel voortgesit. Daarmee is aangesluit by die gebruik wat reeds in die tabernakel en tempel begin is, naamlik die openbare lees van die Skrif (vgl. Deut. 31:10 e.v.; 2 Kon. 23:2; Neh. 8:1-18). Al die elemente van die sinagogale erediens - gebed, Skriflesing en prediking - het dus 'n tempelagtergrond (Beckwith, 1984:71). Die Christelike erediens was 'n voortsetting van die sinagogale erediens maar staan tog ook in teenstelling daarmee.

\subsection{Die Nuwe-Testamentiese samekoms}

Die Christelike erediens het hoofsaaklik voortgespruit uit die sinagogale erediens en die breking van die brood in die bovertrek (Maxwell, 1963:2). Van die begin af was die lees van die Skrif in die raamwerk van lofsange en gebed een van die essensiële elemente in die Christelike erediens. Die klem val egter by die Skriflesing nie soseer op die wet as op die profete nie. Laasgenoemde interpreteer die Christene in die lig van Christus, en in die loop van die tyd is nie net Christelike geskrifte tot die Skriflesing toegevoeg nie maar het hierdie geskrifte die belangrikste plek ingeneem. Die tipiese erediens van die Christelike kerk is dus gegrond op die vereniging van die erediens van die sinagoge en die sakramentele ervaring van die bovertrek, en hierdie vereniging dateer uit die tyd van die Nuwe Testament (Maxwell, 1963:5). In sy eerste brief aan die Korintiërs benadruk Paulus hierdie twee elemente as sleutelfaktore in die erediens (1 Kor. 11:23-30; 15:12-28; vgl. Martin, 1995:225). Cullmann (1953:29) toon oortuigend aan dat elke samekoms om die lees van die Skrif gebou was en dat die breking van die brood hoogs waarskynlik ook tydens elke samekoms plaasgevind het. Hy sê die Skriflesing en die maaltyd van die Here was die basis en die doel van elke samekoms. Die lyn van die bovertrek was die spesifiek nuwe in die Christelike erediens, en die lyn van die sinagoge is gesien as voorbereiding op die lyn van die bovertrek (Barnard, 1981:109). Die Skriflesing volg die lyn wat loop van die tabernakel, die tempel en die sinagoge deur die Nuwe Testament tot vandag toe, en is dus die samebindende faktor deur die eeue heen in die ontmoeting van God met sy volk. Later is by die samekomste van die gemeentes ook uit Paulus se 
briewe voorgelees ( 1 Tes. 5: 27; Kol. 4:16), en hy beveel dat hulle daaraan gehoorsaam moet wees. Die briewe is so gestruktureer dat die voorlees daarvan in die raamwerk van die destydse erediens ingepas het. Die voorlees van die boek Openbaring word in 1:3 as opdrag gegee, en daarin word voorleser (enkelvoud) en hoorders (meervoud) onderskei, waaruit blyk dat die openbare voorlesing veronderstel word.

\subsection{Die eerste eeue}

In die eerste eeue (tot ongeveer Nicea, 325 n.C.) het die heersende patroon voortgeduur. Hierdie patroon is deur die sinagogediens geïnspireer en deur die Nagmaal aangevul en is gestempel is deur die beslissende gebeure in verband met die Persoon en werk van Christus. Die eerste Christelike kerk het volgens Handelinge 2:42 en 46 'n eenvoudige liturgie geken, en die belangrikste elemente van die erediens was die Woordbediening, die viering van die Nagmaal en die gebede, terwyl die Christelike lied ook spoedig 'n plek gekry het (Deddens, 1993:18). Hieruit blyk dat die Skriflesing in die erediens van die vroeë kerk van deurslaggewende belang was. Hierby word by die sinagogale erediens aangesluit, en die ooreenkomste tussen die môrediens van die Sabbat in die sinagoge en die diens vir die kategumene in die vroeë Christelike kerk is besonder opvallend (Deddens, 1993:18). Die voorlesing van die Skrif was egter nie bloot 'n navolging van die gebruik in die sinagoge nie (La Potterie, 1986:218). Dit kom uit dieselfde bewustheid: ons het met God gemeenskap deur die besondere Selfopenbaring van God in sy Woord.

Justinus skryf in 150 n.C. twee apologieë en rig sy eerste aan keiser Antoninus Pius. Vir die verstaan van die erediens is hoofstuk 65-67 belangrik en in hoofstuk 67 sê hy die volgende: "Die herinneringe van die apostels of die geskrifte van die profete word gelees solank as die tyd dit toelaat. As die leser ophou, spreek die president en vermaan en bemoedig ons om hierdie uitstekende voorbeelde na te volg" (Barnard, 1981:159; vgl. Cullman, 1953:30; Webber, 1982:52). Die voorlesing vorm in daardie tyd nie net 'n selfstandige deel van die erediens nie, maar dit is die primêre handeling waaruit ' $n$ kort vermaning/ aanmoediging asook die Nagmaalsdiens voortvloei (Vos \& Pieterse, 1997:142). Hierdie patroon word deurgaans in die eerste drie eeue gevind, byvoorbeeld by Cyprianus van Kartago (ongeveer 246-258). By hom is die wentelpunt van die Sondagse diens die feestelike luister na God deur die lesing van die Skrif as begin van die diens. Die gemeente staan wanneer hierdie handeling plaasvind (ep. 38,2.). Gedurende die eerste eeue is dus 'n primêre plek aan die voorlesing van die Skrif in die erediens gegee. Die bekende gebruik van die sinagogediens om die Ou Testament gereeld voor te lees het op die vroeë kerk oorgegaan. Hier het 'n nuwe element bygekom, naamlik dat ook 'n perikoop uit die Nuwe Testament gereeld gelees is. Spoedig was daar aanduidings van twee lesings uit die Nuwe Testament, naamlik die 
Briewe en die Evangelies. Die lesings het, soos gesien is, 'n stygende lyn vertoon, naamlik eers uit die Ou Testament, dan uit die Briewe en laaste uit die Evangelies (Barnard, 1981:167).

Beginnende by die Konstantynse periode het die verering van God in die erediens al meer tot seremonies verander en het al meer invloede van die misteriegodsdienste waarneembaar geword (Webber, 1982:71). Aan die begin van die sestiende eeu het die Nagmaal in die Westerse kerk 'n dramatiese skouspel geword, waar die klem geval het op die wonder van die transsubstansiasie, gemeng met allerlei bygeloof (Maxwell, 1963:72). In hierdie proses is die Skriflesing en die prediking gedegradeer. In die plek van die Skriflesing (van opeenvolgende gedeeltes of verskillende perikope uit die Skrif) is dikwels lang voorlesings gehou oor die lewe en die legendes oor die sogenaamde heiliges. Die voorlesings uit die $\mathrm{Ou}$ Testament het uiteindelik heeltemal weggeval (Van der Werf, 1976:33). Reformasie was 'n dringende noodsaaklikheid.

\subsection{Die Reformasie}

\section{- Luther}

Die oerbeslissing van die Reformasie was 'n liturgiese beslissing: die herstel van die Skriflesing en Skrifprediking in die erediens. In die tyd van die Reformasie was daar groot onkunde aangaande die Bybel by die volk en ook by die priesters, en die Reformatore wou dit regstel deur onder andere die lectio continua, agtereenvolgende Skriflesing in die erediens. Omdat Luther weer die heerlike Bybelse waarheid van die regverdiging uit genade deur die geloof in die Skrif ontdek het, was die Skriflesing die bepalende middelpunt van sy erediens. Hy skryf in 1523 dat enige element in die erediens ingekort kan word behalwe die Skriflesing en dat erediensdeelnemers by niks soveel baat as by die Woord nie (Thompson, 1980:98). Hy herstel die Skriflesing deur 'n perikoop uit die Briewe en uit die Evangelies te laat lees.

\section{- Calvyn}

Calvyn het in Straatsburg gekom tydens die hoogtepunte van die liturgiese ontwikkeling. Hy beskou selfstandige Skriflesing, Skriflesing waaruit prediking voortvloei en prediking as 'n eenheid onder die noemer Woorddiens of Woorddeel. Hy het self die Skrif as die hoogste gesag vir geloof en lewe gesien (Calvyn, 1984:154), en daarom het sy erediens die Skriflesing en die Skrifprediking as die sentrum daarvan (Brienen, 1987:48). As gevolg hiervan het hy nie net die Skriflesing in ere herstel nie maar ook die Woorddeel en sakramentsdeel van die erediens tot 'n hegte eenheid verbind. Hy hou dwarsdeur sy lewe aan die twee-eenheid van Woord en sakrament vas, al kon hy dit nie prakties elke Sondag deurvoer soos hy graag wou nie. Omdat die erediens ook by Calvyn op sy groot basiese leerstellings gegrond is, was sy liturgie gestempel as 
erediens van die Woord (Rayburn, 1980:18). Hy het eers vooraf die selfstandige Skriflesing laat plaasvind en daarna self die Skriflesing met die oog op die prediking waargeneem (Melton, 1967:14). Vir Calvyn was God absoluut soewerein, en aan Hom behoort al die heerlikheid, eer, lof en bewondering. Daarom is die erediens van Calvyn as ' $n$ diens van openbaring beskryf. In die Skriflesing openbaar God Hom duidelik en praat Hy regstreeks met sy volk.

By Calvyn sien ons die samespel tussen die lewende Woord en die handeling van die gemeente. Hy kies selfs in Straatsburg teen die verabsolutering van die preek as die sentrale element van die erediens, want daardeur word die gemeente tot 'n hoorgemeente verlaag. Hierdie miskenning van die gemeente tot 'n hoorgemeente en die verskraling van die dinamiek van die Woord tot oorskatte prediking maak van die erediensdeelnemers passiewe, onbetrokke toehoorders, en dit laat nie reg geskied aan die dinamiese krag van die Woord van God nie (Bridges, 1998:234). In die liturgieboek van Straatsburg (Van der Werf, 1976: 39) kom die Skriflesing drie maal voor: voorlesing uit die Briewe, die Evangelies en dan daarna eers Skriflesing waaruit die prediking voortvloei (Van der Walt, 1982:47). Omdat die Woord lewend en kragtig is, sê Calvyn, stel Christus Homself en die vrug van sy verlossingswerk daardeur teenwoordig (McCord, 1973:247). Calvyn, as teoloog van die Heilige Gees, bely die duidelikheid van die Skrif onder andere op grond van die verligting deur die Heilige Gees (Brienen, 1987:181). Calvyn het dit sterk beklemtoon dat die Skriflesing en prediking deurlopend moet wees - die lectio continua. Dit gaan dus by hom om die herstel van die erediens soos dit in die vroeë kerk was, en om die verbondenheid met die tradisie van die algemene Christelike kerk.

Calvyn se onmiddellike volgelinge volg hom in die selfstandige Skriflesing na. Knox laat in Skotland gedeeltes van die Ou en Nuwe Testament voorlees vóór die Skriflesing met die oog op die prediking (Maxwell, 1963:124). Omdat hierdie gebruik verval het, het die Skotse Sinode in 1652 bepaal dat 'n hoofstuk uit sowel die $\mathrm{Ou}$ en Nuwe Testament gelees moet word. Telkens wanneer die Skriflesing verskraal of in onbruik raak, is dit as gevolg van die feit dat die prediking baie uitgebreid en intellektualisties aangebied word (Maxwell, 1963:132, 140). In die geskiedenis van die Presbiteriaanse kerke in Engeland het die herstel van die vervalle liturgie telkens met die herinstelling van die selfstandige Skriflesing gepaard gegaan.

\section{- Datheen}

Soos by Zwingli het Datheen die Skriflesing ondergeskik gestel aan die prediking as oorredingsmiddel. Datheen was 'n vurige prediker wat dikwels buite die Paltz "haagpreke" gehou het. Op die provinsiale Sinode van Dordrecht van 1574 is die Londense liturgie deur dié van Datheen verdring en volg die Nederlandse liturgie van toe af die spoor van Datheen. Die prediking word die eintlike bestanddeel 
van die diens, terwyl ander handelinge, ook die Skriflesing, 'n soort voordiens geword het. Daarmee is die diens tot die uiterste toe gereduseer (Van der Werf, 1976:44). Die Sinode bepaal dat by voorkeur uit die Nuwe Testament gepreek moet word en uit die Ou Testament slegs met advies van die kerkraad. Waar die Sinode van Dordrecht (1574) die gereformeerde erediens vermink het, het daaropvolgende sinodes min gedoen om die erediens behoorlik te verantwoord en sinvol gestalte daaraan te gee. Geleidelik is die verskillende elemente van die erediens na vóór die begin van die diens verskuif, onder andere ook die Skriflesing. Onder invloed van die rasionalisme is die preek as die eintlike erediens beskou, en dit is as "leerrede" in plaas van Woordbediening verstaan. Hierdie patroon is grootliks in Suid-Afrika en in die kerke van gereformeerde belydenis in die VSA oorgeplaas.

\subsection{Die twintigste eeu}

In die tweede deel van die negentiende en die begin van die twintigste eeu het 'n ontwaking van die liturgiese bewussyn in Nederland gekom, veral onder leiding van A. Kuyper met sy artikels in die Heraut. Kuyper (1911:266) se slotsom is dat die voorlesing van die Skrif, in onderskeiding van die prediking van die Woord, alleen dan 'n vaste plek in die vergadering van die gelowiges kan inneem indien dit daarin as 'n selfstandige deel van die diens voorkom en as sodanig gereël en beskou word Hy pleit dat stukke uit die Ou en Nuwe Testament wat 'n afgeronde geheel vorm, gelees moet word.

Die ontwaking van die liturgiese bewussyn aan die begin van die twintigste eeu kom onder andere as gevolg van die regte verstaan van die bedoeling van die Skriflesing in die erediens (vgl. Fenwick \& Spinks, 1995:7). Die kern daarvan was: die Woord van God moet nie alleen middellik deur die prediking nie maar veral onmiddellik en regstreeks deur die Skriflesing na die gemeente uitgaan (Burkhard, 1995:40). Die Skriflesing as kommunikatiewe handeling in die erediens volg die lyn wat van die tabernakel, tempel, sinagoge deur die Nuwe Testament tot in die twintigste eeu deurloop, en is dus die (enigste?) saambindende faktor wat dwarsdeur die eeue deurslaggewend is in die ontmoeting van God met sy volk. Tydens die hoofmomente van die geskiedenis was die Skriflesing 'n selfstandige handeling, wat 'n eie funksie gehad het bo en behalwe die Skrifgedeelte wat voorgelees was met die oog op die prediking. 


\section{Op soek na praktyk-teoretiese riglyne vir die samekoms van die gemeente}

\section{1 'n Nuwe bewuswording}

\section{- Binne die Roomse kerk}

In die Roomse Kerk was daar in die jare 1950-1960 'n bewuswording dat Skriflesing uit die Ou Testament nie langer verwaarloos kan word nie. Barrosse (1959:1) toon uit Romeine 15:4 die belangrikheid van die hoor van God se Woord uit die Ou Testament aan. Opsommend sê hy dat dit moet gaan om die voortgang van die openbaring aangaande God in die Ou Testament. Hier is dus 'n pleidooi vir die herstel van die voorlees uit die $\mathrm{Ou}$ Testament op die basis van geselekteerde perikope. Uit dieselfde kringe word gepleit om nog vas te hou aan die voorgeskrewe perikope volgens die kerklike jaar (Kiesler, 1982:379). Laasgenoemde is 'n reaksie op die belangrike besluite wat die Tweede Vatikaanse Konsilie (1963) oor die liturgie en veral die Skriflesing in die liturgie geneem het (Fenwick \& Spinks, 1995:64). Die nuwe Roomse Sondagse voorlesings is seker die noukeurigste beplande in die geskiedenis van die Christendom (White, 1977:843). Meer as 800 konsultante - Katoliek, Protestants en selfs Joods - was by hierdie proses betrokke. Die resultaat is 'n driejaarvoorlesing wat byna die hele Nuwe Testament dek (uitgesonderd 2 en 3 Johannes, Judas) en ook die Ou Testament (behalwe Rigters, Esra, Ester, Obadja, Nahum, Haggai). Meer dele uit die Skrif word vandag in die Roomse erediens gelees as in die meeste van die Protestantse kerke. Die nuwe voorlesings het die tradisionele gebruik om Skriflesings wat om die kerklike jaar vir die $\mathrm{Ou}$ Testament en Evangelies gegroepeer is, gekombineer met die Reformasie se gebruik om die lectio continua uit die briewe te doen. So word dwarsdeur die jaar uit die Ou Testament, Evangelies en Briewe gelees. Op hierdie wyse word die hele Skrif in elke gemeente oor 'n periode van drie jaar deurgewerk (vgl. Reumann, 1977:128 e.v.). 'n Groot segment van die Amerikaanse Lutherse, Anglikaanse en Protestantse kerke het hierdie gebruik oorgeneem (White, 1977:843). Die Tweede Vatikaanse Konsilie het as mikpunt gestel om "die skatte van die Bybel meer oorvloedig oop te maak sodat volop voedsel aan die tafel van God se Woord aan gelowiges gebied kan word". Die feit dat tog nog selektief te werk gegaan is om die Skriflesing in 'n periode van drie jaar in te pas, het kritiek uitgelok (Roose, 1986:368-377).

\section{- In Anglikaanse kringe}

In Anglikaanse kringe is ook aandag gegee aan die gebruik van die volle Woord van God, en daar is onder andere aanbeveel dat 'n klompie "highly suitable Old Testament passages" en die Briewe en Evangelies gelees moet word (Jones, 1967:151). Maxwell (1963:160) toon aan dat die United Church of Canada 'n 
gedeelte uit die Ou Testament of die briewe (of albei) lees, daarna sing en daarna uit die evangelies lees, waarop die preek volg. In die United Methodist Church (VSA) word ook 'n Ou-Testamentiese perikoop en dele uit die briewe en evangelies gelees (Fenwick \& Spinks, 1995:41).

\section{- By die Amerikaanse Protestantisme}

In 1983 dui White (1983:23 e.v.) aan dat die Skriflesing in die Amerikaanse Protestantisme tot ongeveer 1976 'n onderskatte deel van die erediens was. Hy sê dat die Skrif meestal gelees is om preke vandaar te lanseer. Hierin het egter drastiese verandering plaasgevind, en die kerke het saam met ander nieProtestantse kerkgroepe 'n leesrooster begin volg (Vos \& Pieterse, 1997:144). Waar voorheen uit een Skrifdeel gelees is, vind daar tans in die meeste Protestantse kerke drie voorlesings plaas: uit die $\mathrm{Ou}$ Testament, Briewe, Evangelies, met 'n psalm as antwoord. Sodoende word aan die Skrif in die erediens 'n sentrale plek toegeken. Sodoende funksioneer die Skriflesing nie as 'n ondersoek ("resource") van die Christelike erediens (dit wil sê ter wille van prediking) nie maar as die bron ("the very source") van die erediens (White, 1983:24). Die feit dat soveel meer uit die verskeie dele (ook onbekender dele) van die Skrif gelees word, het 'n omvangryker kennis van God en 'n verdieping in die geloof meegebring. Die gevaar om subjektief en eensydig sekere aspekte van die dogma (die liefde of die straf van God), gelei deur die voorkeure van 'n betrokke liturg, te beklemtoon word hierdeur grootliks uitgeskakel (Bailey, 1983:141, 142). White (1983:25) sê dat die grootste geskenk wat die RoomsKatolieke aan die Protestantse erediens gegee het, die reformasie aangaande die voorlesing van die Skrif is (sedert Vatikaan II), net soos prediking die grootste geskenk van die Protestantisme aan die Rooms-Katolieke is. Geen verandering in die erediens was so groot in so 'n kort tyd as die omvangryke beweging na voorlesing en prediking volgens die metode van die lectio continua nie.

\subsection{Die uitwerking op die kerklike lewe}

Die uitwerking van die meerdere en selfstandige Skriflesing op die prediking in hierdie kerke was baie ingrypend. Baie predikers is weggelei van tipologiese en tematiese beklemtonings na eksegetiese prediking. Dit het weer meegebring dat die kwaliteit van prediking grootliks verhoog is (White, 1983:26). Wie met onbekende gedeeltes worstel, groei daardeur, en met die groei van die liturg groei die gemeente ook. Hy sê dat predikers deur die lectio continua gedwing word om hulle "privaat kanon" te laat vaar en om die volledige kanon te aanvaar. Daar is nog leemtes in hierdie gebruik, maar dit was 'n groot verryking vir die kerke wat die liturgiese plek van die Skriflesing herstel het. Op die basis van Calvyn se kommentare het talle kommentare in verband met die vasgestelde leesrooster (volgens lectio continua) ontstaan. In baie gebiede kom predikers saam om die gedeeltes te bestudeer en om saam die rykdom van die liefde van God te begryp 
(Ef. 3:18; vgl. Kim, 1997:109). Op die gebied van die ekumeniese verhoudinge het dit 'n nuwe dimensie geopen, want nou kom gelowiges uit kerkgroepe saam om voor die gesag van die Woord te buig. Vanuit die Skrif word fundamentele ekumenisiteit ("grassroots ecumenism") beoefen (White, 1983:26).

In dele van die gereformeerde wêreld word hierdie tendens ook aangetref. Hier kan verwys word na Deddens (1993:54-65) se invloed in Kanada en Nederland, Van der Laan (1983:217-238) oor die Sondagoggenddiens in die Gereformeerde Kerken in Nederland, Van der Werf (1976:85) en Webber (1982:213-222) se driejaarrooster vir Skriflesing en prediking as slegs enkele voorbeelde van wat tans in Protestantse kringe in die wêreld die gebruik is. Uit hierdie baie beperkte oorsig van die gebruik van selfstandige Skriflesing in ander kerke vandag is dit duidelik dat besonder intensiewe aandag aan die selfstandige Skriflesing gegee word en dat by talle groepe die strewe is om die gebruik van die selfstandige Skriflesing volgens die Nuwe-Testamentiese en vroeë kerk te hervorm.

\subsection{Enkele moontlikhede vir die praktiese toepassing van selfstandige Skriflesing}

Die Skrif moet voorgelees word omdat die gemeente wat vergader, byeengekom het om God regstreeks deur sy Woord en ook middellik deur die prediking te hoor. By die keuse van die Skrifgedeelte met die oog op die prediking is die prediker meestal die een wat alleen die besluit neem. Wanneer 'n deel met die oog op die prediking of ter wille van die selfstandige Skriflesing in die erediens gekies word, beteken hierdie keuse tegelyk die eliminasie van ander dele. Die dele wat sonder opset geëlimineer word, is meestal groot dele van die $\mathrm{Ou}$ Testament en Openbaring. So word 'n groot deel van die Woord van God nooit in die samekomste van die gemeente gehoor nie (White, 1983:842). Die gemeente moet as maatstaf vir die keuse van selfstandige Skriflesing die "onbekender" en minder "gehoorde" boeke in berekening bring.

Die eenheid van die Skrif is 'n grondliggende uitgangspunt van alle reformatoriese teologie (Sloyan, 1989a:529). Die Ou Testament is net so ten volle Woord van God as die volle Nuwe Testament. Saam vorm hierdie twee bundels geskrifte 'n eenheid omdat hulle albei die funksie het om van Christus te getuig. Elk op 'n eie wyse is albei versamelings betrokke op die een openbaring van God Drie-enig (Van der Werf, 1976:84). Daarom moet die doelwit wees om elke Sondag ten minste een keer uit albei voor te lees. Die Skrif is 'n organisme, en daarin is verskeidenheid en dit is nie toevallig nie. Hierdie organiese eenheid en verskeidenheid word in die "contrapuntiek" van die meerdere lesing tot uiting gebring (Blancy, 1986:568). Die lees van die Skrif (een, twee of drie dele) as selfstandige handeling en die Skriflesing waaruit prediking voortvloei en die Skriftuurlike prediking is saam die een groot diens van die Woord. Ook die psalms wat tussen die twee Skriflesings met eiesoortige funksies gesing kan 
word, is steeds deel van die Woorddiens, omdat dit beryming van die Skrif is. In die Woorddiens kom die eenheid en verskeidenheid van die Woord van God tot duidelike uitdrukking. Dit is God wat hierin sy Goddelike openbaring gee, die proklamering van die groot dade van God vir mense en hulle verlossing. Die Bybelse openbaring is ' $\mathrm{n}$ eenheid en in die erediens moet dit as een handeling tot uitdrukking kom. Die beperktheid van die prediker om een aspek van die openbaring (dalk óór) te beklemtoon en weens eie subjektiewe geloofsoortuiging telkens in elke preek te herhaal kan deur meerdere Skriflesing tot 'n groot mate uitgeskakel word.

Dit is van die grootste belang dat in die besluit oor die selfstandige Skriflesing rekening gehou moet word met die geskiedenis, veral die gebruike in die NuweTestamentiese en in die vroeë kerk. Hierdeur word die neiging tot willekeur getemper deur die besluite om die Skriflesing onder die tug van die geskiedenis te plaas. Dit was ook Calvyn se standpunt aangaande die herstel van die liturgie volgens die voorbeeld van die vroeë kerk. Die voorlesing moet uit volledige, afgeronde dele wees en nie 'n klompie kort brokkies nie. Daarom behoort die Skriflesing uit die volle Skrif oor die twee eredienste van die Sondag versprei te word. Daar kan maklik weens die druk van tyd en die begeerte om in een diens uit die $\mathrm{Ou}$ Testament, Briewe en Evangelies voor te lees te kort en klein gedeeltes uit 'n bepaalde gedeelte gelees word. Te lang gedeeltes moet egter nie gebruik word nie (Van der Walt, 1982:47). Die ideaal bly dat op 'n Sondag ten minste die Ou en Nuwe Testament se verskillende soorte stof na vore kom (Van der Werf, 1976:84).

Daar moet gepoog word om die selfstandige Skriflesing ook ten opsigte van die Skriflesing met die oog op die prediking selfstandig te hou (Ward, 1990:35). Te dikwels word die selfstandige Skriflesing gebruik om byvoorbeeld dele wat op die Skriflesing (vir prediking) betrekking het of wat in die prediking aangehaal word, te lees. Daarmee word die selfstandige Skriflesing van die prediking afhanklik gemaak. Selfs indien 'n preekreeks uit 'n Bybelboek aangepak word (bv. Romeine) en ses preke sou uit sestien hoofstukke kom, moet die selfstandige Skriflesing nie aangewend word om die tussengedeeltes voor te lees nie. Die diens van die Woord bestaan uit twee selfstandige dele wat daarop ingestel is om die erediensdeelnemers die ryke verskeidenheid van die een Woord van die sprekende God te laat hoor.

\section{4 'n Riglyn vir toepassing vandag}

Omdat die evangelie, die koms, sterwe en opstanding van Jesus Christus die brandpunt van die Godsopenbaring vorm, moet daar gepoog word om elke Sondag uit die heenwysing na die brandpunt (Ou Testament), die ontvouing van die brandpunt (Briewe, Handelinge, Openbaring) en die brandpunt self (vier Evangelies) te lees (Leclercq, 1984:245). Dit kan volgens die openbarings- 
historiese metode gedoen word waar die Heilige Skrif in die loop van die jaar in hoofmomente volgens onderskeie, vir elke jaar bepaalde, openbaringshistoriese lyne deurgelees word (Vos \& Pieterse, 1997:145; Van der Walt, 1982:47). So word willekeur in 'n groot mate uitgesluit, veral as die gemeente saamwerk in die bepaling van hierdie hoofmomente.

Dit is egter verkiesliker om bepaalde Bybelboeke in hulle geheel voor te lees. Hiermee word vir die lectio continua en in ' $\mathrm{n}$ mate teen die perikoopstelsel gekies. Die perikoopstelsel is sterk aan die kerklike jaar gekoppel, en in baie kerke word die Skriflesing waaruit prediking voortvloei deur die kerklike jaar bepaal (Wegman, 1994:153-157). Waar dit nie gedoen word nie, sou met die tweede diens perikope wat hierop betrekking het, gekies kan word. Die voorlees van volledige Bybelboeke kan saam met die Skriflesing waaruit die prediking voorvloei, beplan word. Wanneer 'n preekreeks in die oggenddiens uit 'n OuTestamentiese boek gelewer word, kan die Briewe en Evangelies in die oggend gelees word, of wanneer 'n preekreeks uit 'n Nuwe-Testamentiese boek kom, kan die selfstandige Skriflesing die oggend uit die Ou Testament kom. Omdat elke gemeente eiesoortige probleme en behoeftes het, is 'n algemene rooster vir selfstandige Skriflesing nie altyd wenslik nie, al het dit ook bepaalde voordele. Kerke in ' $n$ bepaalde omgewing waarvan die samestelling, omstandighede en probleme redelik ooreenstem, kan met mekaar hierin saamwerk. Dit is van wesenlike belang dat die gemeentes hierby betrokke moet wees en dat dit nie net die predikante is wat oor so ' $n$ wesenlik belangrike aspek van die erediens beslis nie (Sloyan, 1989b:136). Teen 'n leesrooster as riglyn vir kerke kan daar nie beswaar wees nie, want dit het geen dwingende gesag nie. Tog kan dit die eiesoortigheid van kerke misken. 'n Gemeente kan in 'n ontleding van sy geestelike stand tot die gevolgtrekking kom dat vermaning vanuit byvoorbeeld Amos nodig is of aansporing uit Hebreërs. Hieroor kan jaarliks aan die hand van evaluering en doelwitstelling besluit word.

\section{5 'n Algemene voorbeeld van 'n jaarlikse beplanning van selfstandige Skriflesing:}

(Oggend- en aandlesing wissel soos oggend- preekreeks uit Ou/ Nuwe Testament wissel)

\begin{tabular}{||l|l|l|l|}
\hline \hline Eerste jaar & Oggenddiens & Aanddiens & Preekreeks \\
\hline \hline & $\begin{array}{l}\text { Deuteronomium } \\
\text { Johannes }\end{array}$ & $\begin{array}{l}\text { Openbaring } \\
\text { Matteus }\end{array}$ & $\begin{array}{l}\text { Prediker } \\
\text { Jesaja }\end{array}$ \\
\hline \hline Tweede jaar & Oggenddiens & Aanddiens & Preekreeks \\
\hline & $\begin{array}{l}\text { Amos, Hosea, } \\
\text { Joël } \\
\text { Romeine/Markus }\end{array}$ & Genesis & Hebreërs \\
& Handelinge & Psalms \\
\hline
\end{tabular}




\subsection{Die moontlike uitwerking van selfstandige Skriflesing op die hedendaagse erediens}

Die uitwerking wat die toepassing van selfstandige Skriflesing in die erediens op ander Protestantse kerke het, kan 'n aanduiding wees van wat dit mag hê op kerke wat dit nog nie as deel van die erediens het nie. Die moontlike uitwerking is die volgende:

- Die gemeente besef dat God lewend teenwoordig is en dat Hy in hierdie kommunikatiewe handeling red, oordeel, opbou en afbreek. Die besef van Coram Deo bring verdieping in die spiritualiteit van die gemeente.

- Die gemeente hoor God regstreeks, sonder tussenkoms van 'n eksegeet helder en duidelik, en die feit dat meerdere dele in die amptelike vergadering aangehoor word, help dat die God van die Woord in sy volle omvang en krag in die erediens werk. Die gemeente word langs hierdie weg al meer opgevoed om selfstandig na God in sy Woord te luister, juis omdat die Woord bedoel is om gehoor te word.

- Die Skrif gaan vir die gemeente oop in sy volle breedte en diepte, verskeidenheid en samehang wanneer hulle as een liggaam van Christus daarna luister. Dit is die hoogste vorm van gemeentebou.

- Die feit dat meer (en dikwels minder bekende) dele gehoor word, bring 'n omvangryker kennis van God en 'n verdieping in die geloof mee.

- Die worsteling van sowel die voorleser as die erediensdeelnemers om die lewende Woord van God te verstaan en te bepeins is 'n sekere aanduiding dat daar groei sal plaasvind.

- Die subjektiewe keuse vir die een Skriflesing per diens word deur die selfstandige Skriflesing in dieselfde diens tot 'n groot mate uitgeskakel.

- So word sowel prediker as gemeente gedwing om 'n privaat en dikwels baie beperkte "kanon" te laat vaar en die volle kanon as maatstaf vir geloof en lewe te erken.

- Die uitwerking op die prediking is groot. Die prediker word deur die aanhoor van verskillende Skrifgedeeltes weggelei van tipologiese, tematiese, moralistiese prediking na eksegese en aktuele Skrifprediking.

\section{Bibliografie}

ALT, A. 1968. The God of the Fathers. Essays on Old Testament history and religion.

Oxford : Blackwell. 
ARNOLD, C.E. 1989. Ephesians: Power and magic. The concept of power in Ephesians in light of its historical setting. Cambridge : Cambridge University Press.

BAILEY, R. 1983. From theory to practice in worship. Review and Expositor, 80:33-52.

BARNARD, A.C. 1981. Die erediens. Pretoria : NG Kerkboekhandel.

BARROSSE, T. 1959. The senses of scripture and the liturgical periscopes. Catholic Biblical Quarterly, 21:1-23.

BECKWITH, R.T. 1984. The daily and weekly worship of the primitive church in relation to its Jewish antecendents. Evangelical Quarterly, 56:65-80.

BILLERBECK, P. 1964. Ein Sinagogengottesdienst in Jesu Tagen. Zeitschrift fur die Neutestamentliche Wissenschaft, 55:143-161.

BLANCY, A. 1986. The Bible and the church service. Reformed World, 39(3):566-581.

BRAAIJ, P.K. 1993. Paulus over Paulus. Exegetische studie van Romeine 7. Kampen : Kok.

BREED, G. \& VENTER, C.J.H. 1996. Sien, hoor en ken. Basisteoretiese perspektiewe op geloofsopvoeding deur onderhouding van die Pasga. 'n Verkenning van Ou-Testamentiese gegewens. In die Skriflig, 30(1):57-72.

BRIDGES, J. 1998. The joy of fearing God. Colorado Springs : Waterbrook Press.

BRIENEN, T. 1987. De liturgie bij Johannes Calvijn. Zijn publikaties en zijn visies. Kampen : De Groot Goudriaan.

BURKHARD, J.J. 1995. The use of Scripture in theology and preaching: Experience, interpretation and ecclesial identity. New Theology Review, 8(1):30-44.

CALVIN, J. 1961. The epistles of Paul, the apostle, to the Romans and the Thessalonians. Grand Rapids : Eerdmans.

CALVIN, J. 1964. The second epistle of Paul, the apostle, to the Corinthians and the epistles to Timothy, Titus and Philemon. Grand Rapids : Eerdmans.

CALVIN, J. 1965. Commentary on a harmony of the Evangelists, Matthew, Mark and Luke. Vol III. Grand Rapids : Eerdmans.

CALVYN kyk Calvin

CALVYN, J. 1984. Institusie van die Christelike Godsdiens. dl. 1. Potchefstroom : CJBF.

CALVYN, J. 1986. Institusie van die Christelike Godsdiens. dl. 2. Potchefstroom : CJBF.

CILLIERS, J. 1996. Die uitwissing van God op die kansel. Ontstellende bevindinge oor SuidAfrikaanse prediking. Kaapstad : Lux Verbi.

COMBRINK, V. 1993. Die betekenis van die eskatologie in die Kolossensebrief vir gemeenteopbou: 'n Diakoniologiese ondersoek. Potchefstroom : PU vir CHO. (Th.D.-proefskrif.)

CORNELIUS, E.M. 1991. Die funksie van die "danksegging(e)" in 1 Tessalonisense. Potchefstroom : PU vir CHO. (M.A.-verhandeling.)

CULLMAN, O. 1953. Early Christian worship. Philadelphia : Westminster Press.

DEDDENS, K. 1993. Where everything points to Him. Neerlandia : Inheritance Publications.

DE KLERK, B.J. 1987. Die Heilige Gees en die verhouding Skriflesing, prediking en gebed in die erediens. Potchefstroom : PU vir CHO. (Th.D.-proefskrif.)

EVANS, C.F. 1990. Saint Luke. London : SCM Press.

FENWICK, J. \& SPINKS, B. 1995. Worship in transition. The liturgical movement in the twentieth century. New York : Continuum.

GOULDER, M.D. 1994. Luke. A new paradigm. Sheffield : Sheffield Academic Press.

GUERRA, A.J. 1995. Romans and the apologetic tradition. Cambridge : Cambridge University Press.

GUTHRIE, D. 1966. New Testament introduction - The Pauline Epistles. London : Tyndale Press.

HAHN, F. 1973. The worship of the Early Church. Philadelphia : Fortress Press. 
HOLLEMAN, J. 1996. Resurrection and parousia. A traditio-historical study of Paul's eschatology in 1 Corinthians 15. Leiden : Brill.

HUST, L.D. 1990. The Epistle to the Hebrews. Its background of thought. Cambridge : Cambridge University Press.

JOHNSON, L.T. 1991. The gospel of Luke. Minnesota : The Liturgical Press.

JONES, D. 1967. Corporate attention to the whole Word of God. Theology, 70:146-157.

KIESLER, C. 1982. The formative influence of liturgy. Studies in Formative Spirituality, 3:377-385.

KIM, H.K. 1997. Preacher and spirituality. A diaconiological study in the light of the Pastoral epistles. Potchefstroom : PU vir CHO. (Th.M.-verhandeling.)

KISTEMAKER, S.J. 1990. Exposition of the Acts of the Apostles. (New Testament Commentary.) Grand Rapids : Baker Book House.

KLIJN, A.F.J. 1975. De brief aan de Hebreën. (De prediking van het Nieuwe Testament). Nijkerk : Callenbach.

KOOLE, J.L. 1946. De zin der liturgie. Amsterdam : Bakker.

KUYPER, A. 1911. Onze eeredienst. Kampen : Kok.

LA POTTERIE, I. 1986. Die lesung der Heiligen Schrift "im Geist": ist die patristische Weise der Bibellesung heute möglich? Internationale Katholische Zeitschrift "Communio", 15(3):209-224.

LECLERCQ, J. 1984. Lectio divina. Worship, 58:239-248.

LIFTIN, D. 1994. St Paul's theology of proclamation in 1 Corinthians 1-4 and Greco-Roman rhetoric. Cambridge : Cambridge University Press.

LOUW, J.P. \& NIDA, A. 1989. Greek-English Lexicon of the New Testament based on semantic domains. Vol 1. New York : United Bible Societies.

MANN, J. 1971. The Bible as read and preached in the old synagoge. New York : Ktav.

MARTIN, D.B. 1995. The Corinthian body. New Haven : Yale University Press.

MAXWELL, W.D. 1963. An outline of Christian worship. London : Oxford University Press.

McCORD, J.I. 1973. Worship in the reformed churches. Reformed World, 32:242-250.

MELTON, 1967. Presbyterian worship in America. Richmond : The John Knox Press.

MILLER, J.D. 1997. The Pastoral letters as composed documents. Cambridge : Cambridge University Press.

MILLIGRAM, A. 1971. Jewish worship. Philadelphia : The Jewish Publication Society of America.

MORITZ, T. 1996. A profound mystery. The use of the Old Testament in Ephesians. Leiden : Brill.

RAYBURN, R.G. 1980. Worship in the Reformed church. Practica, 6:17-32.

REUMANN, J. 1977. A history of lectionaries: from the synagogue at Nazareth to postVatican II. Interpretation, 31:116-130.

ROGERS, V.M. 1977. Some reflections on worship in the Old Testament. Reformed Review, 30:190-197.

ROOSE, P. 1986. Lectio divina among the monks. Communio: International Catholic Review, 13(4):368-377.

SLOYAN, G.S. 1989a. Some suggestions for a Biblical three-year lectionary. Worship, 63(6): 521-535.

SLOYAN, G.S. 1989b. The lectionary as a context for interpretation. Worship, 63(6):131-138.

SQUIRES, J.T. 1993. The plan of God in Luke-Acts. Cambridge : Cambridge University Press.

THOMPSON, B. 1980. Liturgies of the Western church. Philadelphia : Fortress.

TRIMP, C. 1983. De gemeente en haar liturgie. Kampen : Copieerinrichting v.d. Berg. 
VAN DER LAAN, J.H. 1983. Zondagmorgendienst van de Gereformeerde Kerken in Nederland. Gereformeerd Theologisch Tijdschrift, 83: 217-238.

VAN DER WALT, J.J. 1982. Soek die Here in sy tempel. Potchefstroom : Potchefstroomse Teologiese Publikasies.

VAN DER WERF, J. 1976. Kleine liturgiek. 's Gravenhage : Boekencentrum.

VAN HOUWELINGEN, P.H.R. 1993. 2 Petrus en Judas. Testament in tweevoud. Kampen : Kok.

VENTER, C.J.H. 1992. Prakties-Teologiese grondslae van die prediking. Praktiese Teologie in Suid-Afrika, 7(1):1-16.

VLEUGELS, G.A.M. 1997. De brieven aan de Kolossensen en aan de Efesiërs in synopsis. Een studie van hun literaire verwantschap. Potchefstroom : PU vir CHO. (Th.D.proefskrif.)

VON RAD, G. 1962. Old Testament Theology. Vol. I. New York : Harper \& Row.

VOS, C.J.A. \& PIETERSE, H.J.C. 1997. Hoe lieflik in u woning. Studies in Praktiese Teologie. Pretoria : RGN-Uitgewery.

WARD, R.F. 1990. A new look at the lector's art. Liturgy, 8(3):33-37.

WEBBER, R.E. 1982. Worship, old and new. Grand Rapids : Zondervan.

WEGMAN, H. 1994. Achtmaal de Geest gedenken: Schriftlezingen in de paastijd volgens recente leesroosters. Tijdschrift voor Theologie, 34(2):145-168.

WHITE, H.F. 1977. Our apostacy in worship. Christian Century, 94:842-845.

WHITE, J.F. 1983. Recent developments in worship. Review and Expositor, 80:19-31.

YOUNG, E.J. 1972. The book of Isaiah. Vol III. Grand Rapids : Eerdmans. 